\title{
IMPLEMENTASI MANAJEMEN BERBASIS SEKOLAH (MBS) PADA MADRASAH ALIYAH UNGGULAN (STUDI KASUS MAN 4 JAKARTA)
}

\author{
AKHMAD SHUNHAJI \\ Institut PTIQ Jakarta \\ shunhaji.akhmad@yahoo.com \\ ABD MU'ID NAWAWI \\ Universitas Islam Negeri Syarif Hidayatullah Jakarta \\ balesaloe@gmail.com \\ ULFIH QORI KHAIRUNNISA \\ Institut PTIQ Jakarta \\ qoriennisa@gmail.com
}

\begin{abstract}
ABSTRAK
Penelitian ini bertujuan untuk mengetahui implementasi Manajemen Berbasis Sekolah (MBS) di MAN 4 Jakarta khususnya mencari tau mengenai bagaimana otonomi yang dimiliki MAN 4 Jakarta dalam mengembangkan mutu pendidikannya. Untuk menjelaskan keotonomian yang dimiliki MAN 4 tersebut menggunakan Teori Caldwell dan Spinks, diantaranya: pengetahuan (knowledge), teknologi (technology), material (material), kekuasaan (power), manusia (people), waktu (time), dan keuangan (finance), Undang-undang tentan Sistem Pendidikan Nasional, Peraturan Pemerintah (PP) tentang Manajemen Berbasis Sekolah (MBS), Peraturan Menteri Agama (PMA) tantang Penyelenggaraan Pendidikan Madrasah. Penelitian ini menggunakan pendekatan kualitatif dengan metode studi kasus. Pengumpulan data dilakukan dengan wawancara dan pengamatan, sebagai data primer berupa ,dokumen, naskah, dan arsip yang ada di MAN 4 Jakarta, diantaranya buku panduan, buku profil, brosur Penerimaan Peserta Didik Baru (PPDB), data potensi, data prestasi, serta website MAN 4 Jakarta. Sedangkan data sekunder diperoleh dari kepustakaan berupa data pendukung yang diperoleh dari literatur seperti buku-buku, majalah, dan sumber lain yang dianggap relevan dengan sasaran peneltian. Pada kenyataannya di lapangan implementasi Manajemen Berbasis Sekolah (MBS) tidak secara utuh memberikan kebebasan mutlak kepada sekolah/madrasah dalam mengatur sendiri kebijkan sekolahnya, namun tetap harus memenuhi dasar regulasi yang telah ditetapkan pemerintah terutama yang berkaitan dengan program peningkatan melek huruf dan angka (literacy and numeracy), efesiensi, mutu, dan pemerataan pendidikan. Dalam hal-hal tersebut, sekolah/madrasah tidak diperbolehkan untuk berjalan sendiri dengan mengabaikan kebijakan dan standar yang ditetapkan oleh pemerintah yang dipilih secara demokratis. Masukan yang diberikan yaitu pada pelaksanaan Manajemen Berbasis Sekolah (MBS) perlu disertai seperangkat kewajiban serta monitoring dan tuntutan pertanggungjawaban (akuntabel) yang relatif tinggi, untuk menjamin bahwa sekolah/madrasah selain memiliki otonomi juga mempunyai kewajiban melaksanakan kebijakan pemerintah dan memenuhi harapan masyarakat. Dengan demikian, sekolah dituntut mampu menampilkan pengelolaan
\end{abstract}


sumber daya secara transparan, demokratis, tanpa monopoli, dan bertanggung jawab baik terhadap masyarakat maupun pemerintah, dalam rangka meningkatkan kapasitas pelayanan terhadap peserta didik. Terkait dengan Implementasi Manajemen Berbasis Sekolah (MBS) di MAN 4 Jakarta dapat disimpulkan sebagai berikut: Pertama, MAN 4 Jakarta memiliki kewenangan mengatur (otonomi) dalam berbagai aspek, diantaranya: pengetahuan, teknologi, kekuasaan, material, manusia, waktu, dan keuangan itu telah membuat mereka menjadi unggul, karena memiliki kekuatan yang bisa digunakan, memiliki kelemahan yang bisa diatasi, memiliki peluang yang bisa dimanfaatkan, dan mampu mengatasi ancaman menjadi tantangan yang bisa dicarikan solusinya secara bersama-sama. Kedua, MAN 4 Jakarta merupakan salah satu madrasah unggul, dikarenakan memiliki komitmen terhadap pembangunan Sumber Daya Manusia (SDM) dalam Ilmu Pengetahuan dan Teknologi (IPTEK), dan Iman dan Takwa (IMTAK), diantaranya dalam bidang rekrutmen (guru, tenaga kependidikan, siswa dan kegiatan pembelajaran), sarana dan prasarana yang dimiliki, kegiatan evaluasi yang dilakukan secara berkelanjuyan, prestasi akademik dan prestasi non kademik yang tinggi. Ketiga, MAN 4 Jakarta merupakan suatu prototipe madrasah yang sudah melaksanakan konsep Manajemen Berbasis Sekolah (MBS) dengan baik. Sehingga dapat menjadi inspirasi bagi madrasah lainnya yang juga memiliki otonomi namun belum mampu menjadi madrasah yang unggul atau bermutu.

Kata Kunci: Manajemen Berbasis Sekolah dan Madrasah Unggulan

\section{ABSTRACT}

This study aims to determine the implementation of School Based Management (SBM) in MAN 4 Jakarta in particular seeking to know how autonomy that MAN 4 Jakarta has in developing the quality of education. To explain the economics owned by MAN 4, it uses Caldwell and Spinks Theory, including: knowledge, technology, material, power, people, people, time, and finance ), Law on National Education System, Government Regulation (PP) on School Based Management (SBM), Regulation of the Minister of Religion (PMA) challenging the Implementation of Madrasah Education. This research uses a qualitative approach with a case study method. Data collection is done by interviews and observations, as primary data in the form of documents, manuscripts and archives in MAN 4 Jakarta, including manuals, profile books, brochures for New Student Acceptance (PPDB), potential data, achievement data, and websites MAN 4 Jakarta. While secondary data obtained from the literature in the form of supporting data obtained from literature such as books, magazines, and other sources deemed relevant to the research objectives. In reality in the field the implementation of School Based Management (SBM) does not completely give absolute freedom to schools / madrasas in regulating their own school policies, but must still meet the basic regulations set by the government, especially those related to literacy and numeracy improvement programs (literacy and numeracy), efficiency, quality, and educational equity. In these cases, schools / madrasas are not allowed to walk alone by ignoring policies and standards set by democratically elected governments. Input given is that the implementation of School Based Management (SBM) needs to be accompanied by a relatively high set of obligations as well as monitoring and accountability demands, to ensure that schools / madrasas in addition to having autonomy also have the obligation to 
implement government policies and meet the expectations of the community. Thus, schools are required to be able to display resource management transparently, democratically, without monopoly, and to be responsible both to the community and the government, in order to increase the capacity of services for students. Related to the Implementation of School Based Management (SBM) at MAN 4 Jakarta, it can be concluded as follows: First, MAN 4 Jakarta has the authority to regulate (autonomy) in various aspects, including: knowledge, technology, power, material, human, time, and finance. has made them superior, because they have strengths that can be used, have weaknesses that can be overcome, have opportunities that can be exploited, and are able to overcome threats into challenges that can be solved together. Second, MAN 4 Jakarta is one of the superior madrassas, because it has a commitment to the development of Human Resources (HR) in Science and Technology (Science and Technology), and Faith and Takwa (IMTAK), including in the areas of recruitment (teachers, education staff, students and learning activities), facilities and infrastructure owned, evaluation activities carried out continuously, academic achievements and non-academic achievements are high. Third, MAN 4 Jakarta is a prototype madrasa that has implemented the concept of School Based Management (SBM) well. So that it can be an inspiration for other madrassas who also have autonomy but have not been able to become superior or quality madrassas.

Keywords: School and Madrasah Based Management 


\section{A. Pendahuluan}

Sektor pendidikan di Indonesia yang rendah ditandai oleh rendahnya kualitas sumber daya manusia (SDM) yang dihasilkan menyebabkan terjadinya tawuran antar pelajar di berbagai kota yang ditambah dengan sejumlah perilaku mereka yang tergolong kriminal, penyalahgunaan narkoba yang terus meningkat, dan pergaulan bebas di kalangan remaja adalah merupakan bukti bahwa pendidikan di negeri ini tidak berhasil membentuk peserta didik yang memiliki kepribadian islami, berakhlak mulia, dan bertanggung jawab. Fenomena tersebut seringkali dihadapi oleh dunia pendidikan yang apabila tidak segera diatasi secara cepat dan tepat, maka tidak mustahil dunia pendidikan itu akan ditinggalkan oleh zaman. Dengan demikian diperlukan adanya kesadaran untuk menampilkan lembaga pendidikan yang berkualitas dalam usaha memecahkan dan merespon berbagai tantangan baru yang timbul di setiap zaman. ${ }^{1}$ Demikian juga dalam komparasi dunia internasional, mutu pendidikan Indonesia berada pada posisi yang rendah. Hal ini menuntut segenap lembaga pendidikan yang ada di negeri ini untuk bangkit dan berjuang dalam usaha memperbaiki pendidikan agar menjadi lembaga yang berkualitas dan dibanggakan oleh bangsa Indonesia. ${ }^{2}$

Selain itu dalam kinerja pendidikannya Indonesia menunjukkan posisi yang rendah pula. Posisi yang rendah ini dapat dilihat dari dua indikator sekaligus, yaitu indikator makro seperti pencapaian Human Development Index (HDI), pemilikan daya saing, kualitas pendidikan. ${ }^{3}$ Berdasarkan laporan perkembangan indeks pembangunan manusia (HDI), yang telah dikeluarkan oleh United Nations Development Programme (UNDP) PBB pada tahun 2016, menunjukkan bahwa Indonesia berada pada peringkat 113 dari 188 negara dan sebagainya serta indikator mikro seperti prestasi matematika, fisika, kemampuan membaca dan sebagainya. ${ }^{4}$ Dengan rendahnya mutu dan sumber daya manusia yang dihadapi dunia pendidikan, maka pada tingkat sekolah diperlukan adanya pembenahan dalam manajemen pendidikannya.

Suatu hal yang paling menonjol dalam rendahnya mutu pendidikan di Indonesia adalah pada lembaga madrasah yang dikelola oleh Kementrian Agama (Kemenag). Realitas kemerosotan pendidikan madrasah saat ini menunjukkan, bahwa mayoritas kepala madrasah terutama yang swasta masih belum memiliki kualitas, kompetensi, dan profesionalitas yang memadai. Kualitas mereka rata-rata

${ }^{1}$ Abuddin Nata, Manajemen Pendidikan Mengatasi Kelemahan Pendidikan Islam di Indonesia (Bogor: Kencana, 2003), 159.

2 Hari Suderadjat, Sebuah Pengantar: Pendidikan Berbasis Luas (BBE) yang berorientasi padaKecakapan Hidup (Life Skill) (Bandung: CV Cipta Cekas Grafika, 2003), i.

${ }^{3}$ Paul Suparno, Sebuah Pengantar: Kompleksitas Persoalan Pendidikan di Indonesia (Jakarta: Penerbit Buku Kompas, 2006), x.

${ }^{4} \mathrm{Ki}$ Supriyoko, Pembiayaan Pendidikan di Indonesia dalam Pendidikan di Indonesia (Jakarta: PT Kompas Media Nusantara, 2004), 423. 
berada di bawah kepala sekolah umum, baik dalam manajemen, wawasan kurikulum, keterampilan, inovasi, serta kreasi. ${ }^{5}$ Dalam ungkapan yang berbeda Malik Fadjar berpendapat bahwa yang menyebabkan perkembangan pendidikan Islam itu masih memiliki hambatan besar dikarenakan sifatnya yang tertutup dan ortodoks, sehingga belum terbuka terhadap kemajuan ilmu pengetahuan dan teknologi. Inilah yang menyebabkan pendidikan Islam tersingkir dari manajemen pendidikan nasional dan belum dikatakan sebagai lembaga pendidikan alternatif. ${ }^{6}$

Selanjutnya Azyumardi Azra mengemukakan dalam Jurnal Madrasah bahwa kendala manajemen madrasah adalah masih rendahnya visi dan orientasi para pengelola madrasah dalam kaitannya dengan peningkatan mutu madrasah. Sejalan dengan itu, Armai Arief berpendapat bahwa yang menyebabkan madrasah sangat jauh dari profesionalisme bila dibandingkan dengan sekolah-sekolah umum lainnya dikarenakan lemahnya sumber daya manusia, minimnya sarana dan prasarana, serta dana yang dimilikinya itu sangat terbatas. ${ }^{7}$

Dengan rendahnya mutu pendidikan pada jenjang pendidikan dasar dan menengah di Indonesia, khusunya pelaksanaan pendidikan di lingkungan madrasah yang selama ini kurang memuaskan banyak pihak, maka diperlukan adanya upaya untuk meningkatkan kualitas pendidikan. Hal ini senada dengan yang diungkapkan oleh Hari Suderajat bahwa, mutu pendidikan indonesia berada pada posisi yang rendah sehingga hal ini menuntut segenap lembaga pendidikan yang ada di negeri ini untuk bangkit dan berjuang dalam usaha memperbaiki pendidikan agar menjadi lembaga yang berkualitas dan dapat di banggakan oleh bangsa Indonesia. ${ }^{8}$ Upaya peningkatan kualitas pendidikan di lingkungan madrasah dapat dilakukan dengan melakukan reformasi pendidikan, yakni salah satunya dengan menggunakan konsep Manajemen Berbasis Sekolah (MBS) sebagai media dalam meningkatkan kualitas madrasah menuju madrasah unggulan.

Seiring berjalannya waktu, Azyumardi Azra dan Halfian Lubis mengemukakan bahwa lambat laun madrasah dan sekolah Islam mulai menggeliat dan mengejar ketertinggalannya. Hal ini tampaknya ditandai dengan muculnya beberapa sekolah Islam unggulan pada berbagai daerah di Indonesia, seperti SMA Islam Al-Azhar Jakarta, SMA Muhammadiyah 1 Yogyakarta, SMA Unggulan Darul Ulum Jombang, SMA Plus Al-Azhar Medan, SMA Islam Athirah Makasar, SMA Madania Parung Bogor, SMA Plus Muthhahhari Bandung, MAN Insan Cendikia Bogor, SMA Dwiwarna Parung adalah sebagai bukti bahwa lembaga pendidikan Islam mulai bangkit dan berjuang untuk mengejar ketertinggalannya itu. ${ }^{9}$.

${ }^{5}$ Husni Rahim, Madrasah dalam Politik Pendidikan di Indonesia (Jakarta: Logos Wacana Ilmu, 2005), 113-114.

${ }^{6}$ A Malik Fadjar, Madrasah dan Tantanagan Modernitas (Bandung: Mizan, 1998), xi-viii.

${ }^{7}$ Armai Arief, Reformasi Pendidikan Islam (Jakarta: CRSD Press, 2005), 73.

${ }^{8}$ Hari Suderajat, Sebuah Pengantar: Pendidikan Berbasis Luas (BEE) yang berorientasi pada kecakapan hidup (Life Skill)...hal. 1.

9 Azyumardi Azra, Pendidikan Islam: Tradisi dan Modernisasi Menuju Milenium Baru (Jakarta: PT Logos Wacana Ilmu, 2002), 75. 
Dengan munculnya beberapa sekolah Islam dan madrasah yang memiliki paradigma baru dengan cara menyeimbangkan antara kecerdasan sekaligus kesalehan yang dikenal dengan Ilmu Pengetahuan dan Teknologi (IPTEK) dan Iman dan Takwa (IMTAK), sebagaimana pemahaman manusia berkualitas dalam khasanah pemikiran Islam disebut sebagai insan kamil yang mempunyai sifat-sifat antara lain manusia yang selaras (jasmani dan rohani, duniawi dan ukhrawi), manusia moralis (sebagai individu dan sosial), manusia nazhar dan i'tibar (kritis, berijtihad, dinamis,bersikap ilmiah dan berwawasan ke depan), serta menjadi manusia yang memakmurkan bumi. ${ }^{10} \mathrm{Hal}$ ini sangat menarik minat masyarakat, terutama masyarakat muslim kelas menengah ke atas yang ada di perkotaan yang memang tengah mengalami kekeringan spiritual. ${ }^{11}$

Kehadiran madrasah atau sekolah Islam unggulan merupakan bagian penting dari lembaga pendidikan nasional di Indonesia, tentunya diharapkan memiliki peran yang begitu besar dalam menghasilkan generasi penerus bangsa yang layak diacungi jempol. Kemajuannya tidak hanya terletak pada perkembangan sumber daya manusia (SDM) saja, namun juga desain kurikulum yang lebih canggih, dan sistem manajemen yang modern dan demokratis, infrastrukstur dan fasilitas pendidikan yang dimiliki itu memadai dan sesuai dengan kebutuhan kegiatan belajar mengajar siswa-siswi di lingkugan madrasah. ${ }^{12}$

Kehadiran MAN 4 Jakarta sebagai salah satu sekolah Islam di Indonesia tampaknya layak masuk dalam daftar sekolah-sekolah unggulan, madrasah yang berlokasi di Pondok Pinang Jakarta Selatan ini terus menorehkan prestasi-prestasi yang membanggakan. Memang prestasi adalah bagian dari substansi yang melekat dalam visi MAN 4 Jakarta: Pengembangan Pendidikan Islami Unggul dalam Prestasi. Untuk mengawal visi di atas salah satu misi yang diemban sekolah yang sudah mengantongi sertifikasi ISO 9001: 2008 ini adalah "Menjadikan Agama Islam Sebagai Ruh dan Sumber Nilai Pengembangan Madrasah". Selain itu, para lulusan MAN 4 Jakarta banyak yang diterima di Perguruan Tinggi favorit di Indonesia antara lain UGM, ITB, IPB, dan lain sebagainya. Bahkan beberapa diantaranya diterima di perguruan tinggi seperti di Malaysia, melalui program beasiswa. ${ }^{13}$

\section{B. METODE}

Penelitian ini menggunakan jenis penelitian kualitatif dengan metode studi kasus, dimana peneliti berusaha untuk mengetahui bagaimana kondisi riil yang terjadi di MAN 4 Jakarta dalam hal otonomi yang dimiliki sehingga mampu menjadi madrasah unggulan. Pada penelitian ini, teknik pemilihan informasi adalah secara

10 Muhaimin, Pengembangan Kurikulum Pendidikan Agama Islam (Jakarta: PT. Raja Grafindo Persada, 2005), 201

${ }^{11}$ Jajang Jahroni, "Dari Madrasah Nizamiyah Sampai Sekolah Islam Global", dalam Jurnal Komunikasi Dunia Perguruan Madrasah, 2006, 6.

12 Khoirul Umam Sonhaji, "Madrasah Merespon Tantangan Dunia Global”, dalam Jurnal Komunikasi Dunia Perguruan Madrasah, 2006, 8.

${ }^{13} \mathrm{http} / / /$ man4jakarta.kemenag.go.id, diakses pada 25 Juli 2019. 
purposive. Sumber data yang digunakan disini tidak sebagai sumber data yang mewakili populasinya, tetapi mewakili informasi. Berdasarkan kepada akses tertentu yang dianggap memiliki informasi yang berkaitan dengan permasalahan secara mendalam dan dapat dipercaya sebagai sumber yang mantap. Para informan yang dijadikan unit analisis dalam penelitian ini adalah kepala madrasah, wakil kepala madrasah bidang kurikulum, wakil kepala madrasah bidang kesiswaan, wakil kepala madrasah bidang pengembangan mutu, wakil kepala madrasah bidang humas ,wakil kepala madrasah bidang sarana prasarana, kepala Tata Usaha, Pegawai Tata Usaha, dan perwakilan siswa MAN 4 Jakarta.

Untuk memperoleh data yang diperlukan, maka cara pengumpulan data yang dilakukan olehh penulis, diantatranya : observasi, wawancara, studi dokumen, dan triangulasi. Teknik analisis data dalam penelitian ini menggunakan model Miles dan Huberman, yakni aktivitas dalam analisis data kualitatif dilakukan secara interaktif dan berlangsung secara terus menerus sampai tuntas, sehingga datanya sudah jenuh. Aktivitas dalam analisis data, yaitu data reduction, data display, dan conclusion drawing/verification. ${ }^{14}$

\section{HASIL DAN PEMBAHASAN}

Diterbitkannya Undang-Undang Nomor 20 tahun 2003 tentang Sistem Pendidikaan Nasional pasal 51 ayat 1 yang mengamanatkan bahwa: Pengelolaan satuan pendidikan anak usia dini, pendidikaan dasar, dan pendidikan menengah dilaksanakan berdasarkan standar pelayanan minimal dengan prinsip manajemen berbasis sekolah ${ }^{15}$. Sementara dalam Peraturan Pemerintah tentang Standar Pengelolaan Bab VIII bagian I pasal 49 ayat 1 dijelaskan bahwa: Pengelolaan satuan pendidikan pada jenjang pendidikan dasar dan menengah menerapkan manajemen berbasis sekolah yang ditunjukkan dengan kemandirian, kemitraan, keterbukaan dan akuntabilitas. ${ }^{16}$ Undang-Undang dan Peraturan Pemerintah tersebut, pada hakikatnya merupakan wahana bagi usaha untuk memandirikan masyarakat sekolah dan mengurusi rumah tangganya sendiri. Sehingga mereka dalam pengambilan keputusan yang mencakup hajat hidup masyarakat sekolah atau stakeholder, dilibatkan secara aktif.

Dengan ditetapkannya kebijakan mengenai manajemen berbasis sekolah, maka ada beberapa hal yang perlu diperhatikan yaitu:

Pertama, Kewajiban Sekolah, Manajemen berbasis sekolah yang menawarkan keleluasaan pengelolaan sekolah memiliki potensi yang besar dalam menciptakan kepala sekolah, guru, dan pengelola sistem pendidikan profesional. Oleh karena itu, pelaksanaannya perlu disertai seperangkat kewajiban serta monitoring dan tuntutan

${ }^{14}$ Emzir, Metodologi Penelitian Kualitatif: Analisis Data (Jakarta: Raja Grafindo, 2010), 20.

15 Republik Indonesia, Undang-Undang RI Nomor 20 tahun 2003 Tentang Sistem Pendidikan Nasional (Jakarta: Sinar Grafika Offset, 2009), 33.

16 Republik Indonesia, Peraturan Pemerintah Republik Indonesia Nomor 19 tahun 2005 Tentang Standar nasional Pendidikan (Jakarta: Sinar Grafika, 2007), 28. 
pertanggungjawaban (akuntabel) yang relatif tinggi, untuk menjamin bahwa sekolah selain memiliki otonomi juga mempunyai kewajiban melaksanakan kebijakan pemerintah dan memenuhi harapan masyarakat sekolah. Dengan demikian, sekolah dituntut mampu menampilkan pengelolaan sumber daya secara transparan, demokratis, tanpa monopoli, dan bertanggung jawab baik.

Kedua, Kebijakan dan Prioritas Pemerintah. Pemerintah sebagai penanggung jawab pendidikan nasional berhak merumuskan kebijakan-kebijakan yang menjadi prioritas nasioanl terutama yang berkaitan dengan program peningkatan melek huruf dan angka (literacy and numeracy), efesiensi, mutu, dan pemerataan Pendidikan. Dalam hal-hal tersebut, sekolah tidak diperbolehkan untuk berjalan sendiri dengan mengabaikan kebijakan dan standar yang ditetapkan oleh pemerintah yang dipilih secara demokratis. Agar prioritas-prioritas pemerintah dilaksanakan oleh sekolah dan semua aktivitas sekolah dutujukan untuk memberikan pelayanan kepada peserta didik sehingga dapat belajar dengan baik, pemerintah perlu merumuskan seperangkat pedoman umum tentang pelaksanaan MBS. Pedoman-pedoman tersebut, terutama ditujukan untuk menjamin bahwa hasil pendidikan (student outcomes) terevaluasi dengan baik, kebijakan-kebijakan pemerintah dilaksanakan secara terhadap masyarakat maupun pemerintah, dalam rangka meningkatkan kapasitas pelayanan terhadap peserta didik.efektif, sekolah dioperasikan dalam kerangka yang disetujui pemerintah, dan anggaran dibelanjakan sesuai dengan tujuan.

Ketiga, Peranan Orang tua dan Masyarakat, MBS menuntut dukungan tenaga kerja yang terampil dan berkualitas untuk membangkitkan motivasi kerja yang lebih produktif dan memberdayakan otoritas daerah setempat, serta mengefesiensikan sistem dan menghilangkan birokrasi yang tumpah tindih. Untuk kepentingan tersebut, diperlukan partisipasi masyarakat, dan hal ini merupakan salah satu aspek penting dalan manajemen berbasis sekolah. Melalui dewan sekolah (school council), orangtua dan masyarakat dapat berpartisipasi dalam pembuatan berbagai keputusan. Dengan demikian, masyarakat dapat lebih memahami serta mengawasi dan membantu sekolah dalam pengelolaan termasuk kegiatan belajar mengajar. Besarnya partisipasi masyaraakat dalam pengelolaan sekolah tersebut, mungkin dapat menimbulkan rancunya kepentingan anatara sekolah, orangtua, dan masyarakat. Dalam hal ini pemerintah perlu merumuskan bentuk partisipasi (pembagian tugas) setiap unsur secara jelas dan tegas.

Keempat, Peranan Profesionalisme dan Manajerial, Manajemen berbasis sekolah menuntut perubahan-perubahan tingkah laku kepala sekolah, guru dan tenaga administrasi dalam mengoperasikan sekolah. Pelaksanaan MBS berpotensi meningkatkan gesekan peranan yang bersifat profesional dan manajerial. Untuk memenuhi persyaratan pelaksanaan MBS, kepala sekolah, guru dan tenaga administrasi harus memiliki kedua sifat tersebut, yaitu professional dan manajerial. Mereka harus memiliki pengetahuan yang dalam tentang peserta didik dan prinsipprinsip Pendidikan untuk menjamin bahwa segala keputusan penting yang dibuat 
oleh sekolah, didasarkan atas pertimbangan-pertimbangan Pendidikan. Kepala sekolah khusunya, perlu mempelajari dengan teliti, baik kebijakan dan prioritas pemerintah maupun prioritas sekolah sendiri.

Kelima, Pengembangan Profesi. Dalam MBS pemerintah harus menjamin bahwa semua unsur penting tenaga kependidikan menerima pengembangan profesi yang diperlukan untuk mengelola sekolah secara efektif. Agar sekolah dapat mengambil manfaat yang ditawarkan MBS, perlu dikembangkan adanya pusat pengembangan profesi, yang berfungsi sebagai penyedia jasa pelatihan bagi tenaga kependidikan untuk MBS. Selain itu, penting untuk dicatat bahwa sebaiknya sekolah dan masyarakat perlu dilibatkan dalam proses pelaksanaan MBS sedini mungkin. Mereka tidak perlu hanya menunggu, tetapi melibatkan diri dalam diskusi-diskusi tentang MBS dan berinisiatif untuk menyelenggarakan pelatihan tentang aspekaspek yang terkait. ${ }^{17}$ MAN 4 Jakarta secara hirarki merupakan binaan Kantor Wilayah (Kanwil) Kemenag Prov. DKI Jakarta, oleh karena itu, dalam praktik manajemen berbasis sekolah, MAN 4 Jakarta tetap berkewajiban mengikuti standar pengelolaan madrasah yang ditetapkan dalam Peraturan Menteri Agama (PMA).

\section{Kementerian Agama (Kemenag) dan MAN 4 Jakarta}

Kementrian Agama secara bertahap dan terus menerus mengembangkan program-program peningkatan dan perluasan akses serta peningkatan mutu madrasah. Dalam upaya meningkatkan akses, mutu, dan daya saing, serta relevansi pendidikan madrasah maka Kementrian Agama mengatur penyelenggaraan pendidikan di madrasah berdasarkan Peraturan Menteri Agama (PMA) Nomor 90 Tahun 2013 Tentang Penyelenggaraan Pendidikan Madrasah. Dalam PMA No 90 tahun 2013 pada BAB XI Pasal 41 ayat 1 disebutkan bahwa Pengelolaan madrasah dilakukan dengan menerapkan manajemen berbasis madrasah yang dilaksanakan dengan prinsip keadilan, kemandirian, kemitraan dan partisipasi, nirlaba, efisiensi, efektivitas, dan akuntabilitas. ${ }^{18}$

MAN 4 Jakarta merupakan institusi negeri/pemerintah. Oleh karena pendirian MAN 4 Jakarta diselenggarakan oleh pemerintah maka harus memenuhi stándar nasional pendidikan. Namun demikian penyelenggaraan pendidikan di madrasah ini berdasarkan prinsip manajemen berbasis sekolah, artinya MAN 4 Jakarta diberikan kewenangan dalam menentukan arah kebijakan pendidikannya dengan tetap memperhatikan dasar hukum yang telah ditetapkan oleh pemerintah khusunya dalam hal ini Kementrian Agama. ${ }^{19}$ Dalam pelaksanaan MBS MAN 4 Jakarta melakukan inovasi-inovasi dalam banyak hal, baik itu inovasi kurikulum, inovasi dalam Penerimaan Peserta Didik Baru (PPDB), inovasi dalam pengembangan mutu, inovasi dalam sarana prasarana, dan lain sebagainya, MAN 4 Jakarta memberikan pelayanan pendidikan untuk semua siswa, tidak membeda-bedakan apakah dia anak

${ }^{17}$ Rohiat, Manajemen Sekolah (Bandung: PT Refika Aditama, 2012), 29.

18 PMA No 90 tahun 2013 BAB XI Pasal 41 ayat (1)

19 Wawancara dengan Kepala Madrasah, Bapak Aceng Solihin, pada Senin, 23 September 2019 
pejabat atau bukan, kemudian mandiri dalam mengambil keputusan mengenai program pendidikan madrasah, membangun kemitraan orangtua wali murid, melibatkan partisipasi masyarakat sekitar pada kegiatan sosial madrasah, dan melaporkan pertanggungjawaban pelaksanaan program maupun kegiatan yang sumber dananya dari pemerintah maupun dari komite secara akuntabel. ${ }^{20}$

Adapun Kemenag mengatur dasar-dasar hukum dalam beebrapa hal yaitu: Pertama dalam hal kurikulum, seperti pendampingan madarasah tentang pelaksanaan kurikulum yang berlaku, penggandaan buku PAI dan Bahasa Arab sesuai kurikulum yang berlaku. Kedua dalam hal peserta didik, seperti pemberian dana BOS, pemberian bantuan dan sosialisasi program Kartu Indonesia Pintar (KIP) kepada siswa. Ketiga tentang kebijakan berkaitan dengan guru seperti peningkatan kualifikasi S1 guru madrasah, sertifikasi guru madrasah mapel umum. Keempat dalam hal tenaga pendidikan seperti peningkatan kompetensi PTK, peningkatan kualifikasi pendidikan S2 bagi PTK (Guru, Calon Kepala Madrasah, dan Calon Pengawas), pemberian penghargaan dan perlindungan kepada PTK madrasah. Kelima dalam hal sarana prasarana seperti rehabilitasi sedang dan berat, kelengkapan sarana dan prasarana antara lain sarana olah-raga dan seni, sarana laboratorium sains, perpustakaan. Keenam dalam hal mutu, seperti Pemberdayaan KKM dan MGMP, Penyiapan madrasah untuk ditingkatkan mutu akreditasinya. ${ }^{21}$

Dengan demikian, maka dapat dikatakan bahwa Kementerian Agama (Kemenag) tetap memiliki regulasi utama yang diprioritaskan pada peningkatan akses dan mutu sarana dan prasarana pendidikan, siswa, pendidik dan tenaga kependidikan, kelembagaan, dan kurikulum pembelajaran madrasah, namun tetap memberikan kewenangan pada MAN 4 Jakarta dalam melakukan inovasi atau pengembangan-pengembangan sesuai dengan kebutuhan MAN 4 Jakarta dan masyarakat sekitar.

\section{Implementasi Manajemen berbasis sekolah di MAN 4 Jakarta}

Implementasi Manajemen Berbasis Sekolah (MBS) di MAN 4 Jakarta, dilaksanakan dalam beberapa aspek yaitu:

a. Otonomi dalam pengetahuan

Pengetahuan yang dimaksud disini adalah kurikulum. Dalam beberapa literatur disebutkan bahwa keberhasilan manajemen kurikulum tidak terlepas dari pelaksanaan manajemen berbasis sekolah (MBS). ${ }^{22}$ Dalam PMA No 90 Tahun 2013, Pasal 28 ayat 1 Kurikulum MA terdiri dari: a. muatan umum; b. muatan peminatan akademik; dan c. muatan pilihan lintas minat atau pendalaman minat. Muatan umum sebagaimana dimaksud terdiri dari: a. pendidikan agama; $b$. pendidikan kewarganegaraan; c. bahasa; d. matematika; e. ilmu pengetahuan alam; f. ilmu pengetahuan sosial; g. seni dan budaya; h. pendidikan jasmani dan olahraga; i.

\footnotetext{
${ }^{20}$ Wawancara dengan Wakil Kepala Madrasah, Ibu Lisnur pada Kamis, 25 Juli 2019

${ }^{21} \mathrm{http}$ ://pendis.kemenag.go.id/, diakses pada 15 September 2019

22 Rusman, Manajemen Kurikulum (Jakarta: Rajawali Press, 2011), 2.
} 
keterampilan/kejuruan; dan j. muatan lokal. Muatan peminatan akademik pada MA sebagaimana dimaksud pada terdiri dari: a. matematika dan ilmu pengetahuan alam; b. ilmu pengetahuan sosial; c. bahasa dan budaya; atau d. keagamaan. Muatan pilihan lintas minat atau pendalaman minat ketentuan lebih lanjut ditetapkan oleh Direktur Jenderal Mata pelajaran bahasa sebagaimana dikembangkan menjadi 3 (tiga) mata pelajaran, yaitu: a. bahasa Indonesia; b. bahasa Inggris; dan bahasa Arab. ${ }^{23}$

Adapun kurikulum yang ada di MAN 4 Jakarta merupakan hasil diversifikasi atau pengayaan dari kurikulum nasional yang ditambah dengan program-program penunjang kurikulum yang mengacu pada siswa sebagai pusat pembelajaran (student learning center). Selain menerapkan Kurikulum K13 dan kurikulum Kementrian Agama. MAN 4 Jakarta melakukan inovasi berdasarkan analisis kebutuhan masyarakat, yaitu melaksanakan kurikulum Cambridge, kemudian melakukan pengembangan dalam mata pelajaran dengan memasukkan bahasa Jepang dan Jerman untuk pilihan lintas minat, dan mendesain salah satu program jurusan yang fokus pada basic knowledge of science melalui kelas yang menggunakan kurikulum percepatan yaitu kelas Olimpiade Siswa Nasional (OSN) dan Kompetensi Sains Madrasah, serta basic knowledge of technology dengan membuat program technopreneurship yang dimasukkan ke dalam mata pelajaran kewirausahaan. ${ }^{24}$

\section{b. Otonomi dalam Material dan Teknologi}

Dari segi pemenuhan sarana dan prasarana pendidikan, MAN 4 Jakarta sudah melebihi dari standar yang ditetapkan dalam peraturan Kementrian Agama. Sarana dan prasarana yang dimiliki MAN 4 Jakarta sudah cukup memadai, diantaranya : ruang kelas lengkap dengan LCD dan AC, Laboratorium Komputer, Bahasa, Fisika, Kimia, Biologi, IPS, Ruang Kesenian, Masjid, Ruang Internet (server), Hotspot (wifi) seluruh area, mesin finger absen, Lapangan Sepakbola, Basket, Futsal, Volley, Bulutangkis, Tenis meja, Ruang Multimedia, Ruang Workshop, Ruang MGMP/Guru, Ruang TU, Ruang Kepala Madrasah, Ruang OSIS, Ruang Perpustakaan, Ruang PMR/UKS, Ruang Pramuka, Ruang, Ruang Koperasi, Parkir, Masjid, Kamar Mandi Siswa dan Guru, Kamar mandi khusus penyandang disabilitas, Ruang dapur, Ruang BK, Asrama Putra dan Putri.

\section{c. Otonomi dalam Kekuasaan}

Dalam desentralisasi mengenai kekuasaan, Kepala MAN 4 Jakarta memiliki keleluasaan dalam melakukan berbagai keputusan yang berkaitan dengan kebijakan pendidikan. Sebagaimana yang dicantumkan dalam PMA No 90 Tahun 2013 Tentang Pengelolaan Madrasah Pasal 43 bahwa Kepala madrasah adalah

23 PMA No 90 tahun 2013, Pasal 28 ayat 1

24 Wawancara dengan Wakil Kepala Madrasah Bagian Kurikulum MAN 4 Jakarta, Kamis, 12 September 2019. 
penanggung jawab pengelolaan pendidikan di madrasah. ${ }^{25}$ Menurut keterangan kepala MAN 4 Jakarta, beliau rutin mengadakan rapat mingguan untuk koordinasi kegiatan apa saja yang akan dilakukan selama seminggu yaitu rapat pada hari senin, dan kemudian mengadakan rapat hari jum'at untuk mengevaluasi kegiatan yang sudah dilakukan selama seminggu. Adapun selain itu Kepala MAN 4 Jakarta memiliki keleluasaan dalam melakukan berbagai keputusan yang berkaitan dengan kebijakan pendidikann yakni: dalam penentuan program tahunan madrasah, selalu dilakukan melalui mekanisme rapat kerja yang diikuti oleh seluruh pegawai. Prinsip yang dilakukan dalam pengambilan keputusan menurut Kepala Madrasah MAN 4 Jakarta dalah prinsip bottom-up yaitu kepala Madrasah mendengarkan aspirasi dari bawah mengenai kebutuhan maupun kendala yang dihadapi MAN 4 Jakarta. ${ }^{26}$

\section{d. Otonomi dalam Manusia}

Dalam perekrutan Pendidik dan Tenaga Kependidikan MAN 4 Jakarta betulbetul selektif dalam memilih tenaga pengajar yang memiliki kapabilitas di bidangnya tidak hanya dari segi kualitas, tetapi juga dari latar belakang pendidikannya. Untuk mencapai kualitas kegiatan belajar mengajar di MAN 4 Jakarta, maka disediakan guru-guru dengan latar belakang pendidikan minimal sarjana S1 sesuai dengan bidang keahliannya serta mengadakan tes berupa wawancara, micro teaching, baca al-Qur'an, bagi guru-guru non pns, sedangkan bagi guru PNS, pihak MAN 4 Jakarta mengajukan kepada Kemenag. ${ }^{27}$

Adapun dalam Penerimaan Peserta Didik Baru (PPDB). Kegiatan ini dilakukan secara obyektif, transparan, dan akuntabel sebagaimana tertuang dalam aturan MAN 4 Jakarta yang berdasarkan kriteria hasil ujian nasional, dan juga sesuai dengan daya tampung. Dalam pelaksanaan PPDB, MAN 4 Jakarta mengikuti regulasi Kemenag pada PPDB jalur regular dan jalur madrasah, kemudian melakukan pengembangan dengan membuka jalur Cambridge, Jalur asrama OSN, Jalur prestasi, Jalur Mandiri dan Jalur Bina Lingkungan yang dikhususkan untuk masyarakat setempat.

Dalam Kegiatan Kemajuan Belajar. MAN 4 Jakarta memiliki 4 (empat) program kegiatan kemajuan belajar, diantaranya, a) program pengayaan adalah suatu kegiatan penguatan konsep pelajaran tertentu yang terintegrasi dalam jam regular; b) Program privat adalah rancangan pengajaran tambahan oleh orang yang memberi pelajaran kepada seseorang atau sejumlah kecil siswa di asrama; c) Program intensif adalah program tambahan yang diberikan kepada siswa kelas XII dalam rangka mempersiapkan Ujian Nasional (UN); d) Klinik Mata Pelajaran di dalam setiap kegiatan pembelajaran terutama pada bidang studi yang dianggap berat oleh siswa; e) program matrikulasi, program ini bertujuan untuk

\footnotetext{
25 PMA No 90 Tahun 2013 Tentang Pengelolaan Pasal 43

${ }^{26}$ Wawancara dengan Kepala Madrasah, pada, Senin, 23 September 2019.

27 Wawancara dengan, Kepala Tata Usaha MAN 4 Jakarta, Kamis 16 September 2019.
} 
menyamaratakan persepsi awal siswa di awal tahun pelajaran, karena input yang diterima MAN 4 sangat beragam.

\section{e. Otonomi dalam Waktu}

Dalam pengaturan waktu, MAN 4 Jakarta memiliki kewenangan sendiri, karena mengingat madrasah ini sebagi sekolah berasrama (boarding school), sehingga memiliki ciri khas tersendiri dalam jadwal kegiatan sehari-harinya. Penyusunan waktu ini disusun berdasarkan struktur kurikulum MAN 4 Jakarta yang dilaksanakan sejak pagi sampai siang hari atau disesuaikan dengan kepentingan pendidikan di MAN 4 Jakarta. Jadwal tersebut terintegrasi dengan kegiatan siswa sehari hari di lingkungan tersebut. Para siswa/siswi yang tinggal di asrama selain intensif belajar mata pelajaran yang termasuk dalam kurikulum Olimpiade Siswa Nasional (OSN) seperti Kimia, Fisika, Biologi, Ekonomi, Geografi, Sejarah, juga akan mendapatkan kesempatan belajar agama lebih banyak dengan diadakannya kajian kitab kuning, kajian tafsir, tilawah, tahfiz intensif, dan Bahasa Arab.

\section{f. Otonomi dalam Keuangan}

Pengelolaan keuangan di sekolah/madrasah terutama pengalokasian atau penggunaan uang sudah sepantasnya dilakukan oleh sekolah/madrasah. Hal ini juga didasari oleh kenyataan bahwa sekolah/madrasah yang paling memahami kebutuhannya sehingga desentralisasi pengalokasian atau penggunaan uang harus dilimpahkan ke sekolah/madrasah. sekolah/madrasah juga harus diberi kebebasan untuk melakukan kegiatan-kegiatan yang mendatangkan penghasilan (income generating activities) sehingga sumber keuangan tidak semata-mata tergantung hanya kepada pemerintah. Adapun sumber utama pendanaan MAN 4 Jakarta itu dari pemerintah yakni APBN berupa DIPA, dan APBD berupa dana BOP. Selain dari APBN dan APBD, sumber pendanaan MAN 4 Jakarta juga dari masyarakat dalam hal ini komite. Pada pengalokasian nya MAN 4 Jakarta diberikan kewenangan dalam mengatur, namun jika ada program-program pengembangan dari MAN 4 Jakarta yang tidak di cover dana APBN dan APBD maka menggunakan dana dari komite. Biasanya program yang dibiayai komite adalah program yang berkaitan langsung dengan kegiatan siswa dan pertanggung jawabannya dilaporkan pada komite, contohnya adalah program intensif pembelajaran.

\section{KESIMPULAN}

Berdasarkan uraian-uraian penelitian terhadap data-data yang ditemukan maka dapat disimpulkan sebagai berikut:

a. MAN 4 Jakarta merupakan madrasah yang memiliki kewenangan mengatur (otonomi) dalam berbagai aspek, diantaranya: pengetahuan, teknologi, kekuasaan, material, manusia, waktu, dan keuangan itu telah membuat mereka menjadi unggul, karena memiliki kekuatan yang bisa digunakan, memiliki 
kelemahan yang bisa diatasi, memiliki peluang yang bisa dimanfaatkan, dan mampu mengatasi ancaman menjadi tantangan yang bisa dicarikan solusinya secara bersama-sama.

b. MAN 4 Jakarta merupakan salah satu madrasah unggul, dikarenakan memiliki komitmen terhadap pembangunan Sumber Daya Manusia (SDM) dalam Ilmu Pengetahuan dan Teknologi (IPTEK), dan Iman dan Takwa (IMTAK), diantaranya dalam bidang rekrutmen (guru, tenaga kependidikan, siswa dan kegiatan pembelajaran), sarana dan prasarana yang dimiliki, kegiatan evaluasi yang dilakukan secara berkelanjuyan, prestasi akademik dan prestasi non kademiik yang tinggi.

c. MAN 4 Jakarta merupakan suatu prototipe madrasah yang sudah melaksanakan konsep Manajemen Berbasis Sekolah (MBS) dengan baik dan professional. Walaupun pada tahun ajaran 2019/2020 sudah mulai ada yang dibatasi pada beberapa aspek, diantaranya: kekuasaan dan manusia, akan tetapi MAN 4 Jakarta tetap berdaya dalam menjalankan pendidikannya.

Sementara implikasi dalam penelitian ini meliputi 1) Implikasi teoritis, yaitu: untuk menngetahui penerapan manajemen berbasis sekolah adalah desntralisasi yang sistematis pada otoritas dan tanggng jawab sekolah untuk membuat keputusan terkait penyelenggaraan sekolah yaitu kurikulum, standar, dan akuntabilitas, penelitian ini menambahkan variable lainnya yaitu dalam pengetahuan (knowledge), teknologi (technology), kekuasaan (power), material (material), manusia (people), waktu (time), dan keuangan (finance); 2) Implikasi praktis, yaitu analisis mengenai manajemen berbasis sekolah pada madrasah unggulan, penelitian ini dapat digunakan sebagai masukan bagi pemangku pendidikan pada madrasah yang sudah diberikan hak otonomi untuk mengeksplor potensi madrasahnya agar bisa menjadi madrasah unggul. 


\section{DAFTAR PUSTAKA}

Arief, Armai, Reformasi Pendidikan Islam, Jakarta: CRSD Press, 2005.

Azra, Azyumardi, Pendidikan Islam: Tradisi dan Modernisasi Menuju Milenium Baru, Jakarta: PT Logos Wacana Ilmu, 2002.

Emzir, Metodologi Penelitian Kualitatif: Analisis Data, Jakarta: Raja Grafindo, 2010.

Fachruddin, Fuad, Madrasah Model: Indikator Obyektif dan Operasionalisasi dalam Bulletin UIN Syarif Hidayatullah: Media Komunikasi dan Informasi Sivitas Akademika, Edisi N0. 305 Oktober 2005.

Fadjar, A Malik, Madrasah dan Tantanagan Modernitas, Bandung: Mizan, 1998.

Jahroni, Jajang, Dari Madrasah Nizamiyah Sampai Sekolah Islam Global, dalam Jurnal Komunikasi Dunia Perguruan Madrasah, Jakarta: Pusat Pengkajian Islam dan Masyarakat (PPIM) UIN Jakarta, 2006.

Muhaimin, Pengembangan Kurikulum Pendidikan Agama Islam. Jakarta: PT. Raja Grafindo Persada, 2005.

Nata, Abuddin, Manajemen Pendidikan Mengatasi Kelemahan Pendidikan Islam di Indonesia, Bogor: Kencana, 2003.

Peraturan Menteri Agama No 90 tahun 2013 Tentang Penyelenggaraan Pendidikan Madrasah

Peraturan Pemerintah Republik Indonesia Nomor 19 tahun 2005 Tentang Standar nasional Pendidikan

Rahim, Husni, Madrasah dalam Politik Pendidikan di Indonesia, Jakarta: Logos Wacana Ilmu, 2005.

Rohiat, Manajemen Sekolah; Bandung: PT Refika Aditama, 2012.

Rusman, Manajemen Kurikulum, Jakarta: Rajawali Pers, 2011.

Sagala, Syaiful, Manajemen Berbasis Sekolah dam Masyarakat; Strrategi Memenangkan Peningkatan Mutu, Jakarta: Nimas Multima, 2004.

Sonhaji, Khoirul Umam, Madrasah Merespon Tantangan Dunia Global, dalam Jurnal Komunikasi Dunia Perguruan Madrasah, Jakarta: Pusat Pusat Pengkajian Islam dan Masyarakat (PPIM) UIN Jakarta, 2006

Suderadjat, Hari, Sebuah Pengantar: Pendidikan Berbasis Luas (BBE) yang berorientasi padaKecakapan Hidup (Life Skill), Bandung:CV Cipta Cekas Grafika, 2003.

Suparno, Paul, Sebuah Pengantar: Kompleksitas Persoalan Pendidikan di Indonesia, Jakarta: Penerbit Buku Kompas, 2006.

Supriyoko, Ki, Pembiayaan Pendidikan di Indonesia dalam Pendidikan di Indonesia, Jakarta: PT Kompas Media Nusantara, 2004.

Tentang Kebijakan Kemenag diakses dari http://pendis.kemenag.go.id/, diakses pada 15 September 2019.

Tentang MAN 4 Jakarta diakses dari http://man4jakarta.kemenag.go.id, diunduh pada 25 Juli 2019.

Undang-Undang RI Nomor 20 tahun 2003 Tentang Sistem Pendidikan Nasional. 